\title{
KONSEKUENSI YURIDIS PUTUSAN MAHKAMAH KONSTITUSI NOMOR 13/PUU-XV/2017 TERHADAP TENAGA KERJA YANG MEMILIKI IKATAN PERKAWINAN DENGAN SESAMA TENAGA KERJA DALAM SATU PERUSAHAAN
}

\author{
Oleh: \\ I Nyoman Agus Trisnadiasa, Dewa Putu Tagel \\ Email:agustrisnadiasa@undwi.ac.id \\ Dosen Fakultas Hukum Universitas Dwijendra Denpasar \\ Dosen Jurusan Hukum Fakultas Darma Duta IHDN Denpasar
}

\begin{abstract}
The Problems that emerged in a marriage in Indonesia, visible seen in arrangement marriage in tje workplace, each worker / laborers in one company will undertake ongoing marriage, some companies both by the governmenr, and private, establishes a clause that limits the right to undertake ongoing marriage between workers/laborers in one company. That the existence of a clause the termination of employment, so that constitutional court thought the regulation contraty contrary constitutional the art 28D paragraph 1 the contitution of 1945 that everyone is entitled to form family and to survive through marriage legitimate. Expected for company follow the constitutional court decisions.
\end{abstract}

Keyword : Marriage, Labor, Agreement

\section{A. PENDAHULUAN}

\section{Latar belakang Masalah}

Perkawinan adalah suatu hal yang penting dalam realita kehidupan umat manusia.'Perkawinan juga merupakan kebutuhan hidup seluru umat manusia sejak zaman dahulu hingga sekarang. Dari perkawinan akan timbul hubungan hukum antara suami istri, sehingga dengan perkawinan yang dilakukan menimbulkan akibat hukum. Adanya hukum ini erat sekali hubungannya dengan sahnya perbuatan hukum. Jika suatu perkawinan yang dilakukan tidak menurut hukum, maka akibat yang timbul oleh perkawinan itu pun dnegan sendirinya tidak sah.

Pasal 1 Undang-undang No. 1 Tahun 1974 tentang perkawinan (selanjutnya disebut UU perkawinan) menyebutkan bahwa "perkawinan adalah ikatan lahir batin seorang pria dengan seorang wanita sebagai suami istri sebagai tujuan membentuk keluarga yang bahagia dan kekal berdasarkan Ketuhanan yang Maha Esa. Berdasarkan Pasal 1 UU Perkawinan, perkawinan merupakan suatu ikatan suci yang terjalin antara seorang laki-laki dengan seorang perempuan. Suci dalam arti ikatan yang terjalin didasarkan atas dasar suka sama suka dan tidak ada paksaan serta didasari atas keyakinan dan kepercayaan yang dianut. Selanjutnya pada ketentuan Pasal 2 ayat 1 UU Perkawinan menyatakan bahwa perkawinan adalah sah, apabila dilakukan menurut hukum masing-masing agamanya dan kepercayaannya. Kemudian diatur lebih lanjut pada ayat 2, bahwa tiap-tiap perkawinan dicatat menurut peraturan perundang-undang yang berlaku.

Permasalahan yang muncul dalam perkawinan di Indonesia, nampak terlihat pada pengaturan perkawinan dalam dunia kerja, setiap pekerja/buruh dalam satu perusahaan yang akan 
melangsungkan perkawinan, beberapa perusahaan baik pemerintah, maupun swasta, menetapkan suatu klausul yang membatasi hak untuk melangsungkan perkawinan antar pekerja/buruh dalam satu perusahaan. Ketentuan tersebut secara eksplisit dibenarkan dalam Undang-undang No. 13 Tahun 2003 tentang Ketenagakerjaan (selanjutnya disebut UU Ketenagakerjaan). Berdasarkan hal tersebut adanya suatu norma yang bertentangan, hal ini timbul secara ekspilit pada Pasal 153 ayat 1 Huruf $f$ UU Ketenagakerjaan yang menyatakan bahwa

Pengusaha dilarang melakukan pemutusan hubungan kerja dengan alasan:

f. pekerja/buruh mempunyai pertalian darah/atau ikatan perkawinan dengan pekerja/buruh lainnya didalam satu perusahaan, kecuali telah diatur dalam perjanjian kerja, peraturan perusahaan, atau perjanjian kerja bersama.

Bahwa adanya suatu klausul yang dapat membatasi hak untuk melangsungkan perkawinan antar pekerja/buruh dalam satu perusahaan yang tentunya akan menimbulkan pemutusan hubungan kerja, sehingga akan bertentangan dengan konstitusional yakni Pasal 28D Ayat 1 UUD NRI 1945 bahwa setiap orang berhak membentuk keluarga dan melanjutkan keturunan yang melalui perkawinan yang sah.

Perkawinan sesama pegawai dalam suatu perusahaan sebenarnya juga memberikan dampak positif seperti keuntungan perusahaan karena dapat menghemat pengeluaran perusahaan dalam hal menanggung biaya kesehatan keluarga pekerja disebabkan apabila suami isteri bekerja dalam satu perusahaan yang sama maka perusahaan hanya menanggung 1 (satu) orang pekerja beserta keluarga tetapi perusahaan memiliki 2 (dua) orang pekerja, dimana suami atau isteri yang menanggung sesuai yang didaftarkan ke perusahaan dibandingkan dengan suami yang mempunyai isteri/ ibu rumah tangga maka perusahaan hanya mendapatkan 1 (satu) orang pekerja tetapi perusahaan tetap menanggung isteri dan anak-anak pekerja tersebut.

Berdasarkan pemaparan diatas, sangat menarik untuk dibahas lebih lanjut mengenai permasalahan Konsekuensi Yuridis Putusan MK Nomor 13/PUU-XV/2017 Terhadap tenaga kerja yang memiliki ikatan perkawinan dengan sesama tenaga kerja dalam satu perusahaan

\subsection{Rumusan Masalah}

1. Apakah tenaga kerja dapat melangsungkan perkawinan dengan sesama tenaga kerja dalam satu perusahaan berdasarkan ketentuan Pasal 153 ayat (1) huruf F UU Tenagakerjaan?

2. Bagaimakah kedudukan hukum tenaga kerja yang memiliki ikatan perkawinan dengan sesama tenaga kerja dalam satu perusahaan pasca Putusan MK Nomor 13/PUU-XV/2017?

\section{A. PEMBAHASAN \\ 1. Polemik perkawinan antar sesama tenaga kerja dalam satu perusahan ditinjau dari Undang-undang No 13 tahun 2003 tentang Ketenagakerjaan}

Masalah perkawinan merupakan masalah yang komplek, hal ini tidak hanya terjadi antar agama yang berbeda, agama yang sama namun berbeda pendapat, tetapi juga perkawinan yang dilaksanakan oleh sesama pekerja dalam satu perusahaan.

Ketentuan dalam perjanjian kerja ataupun peraturan perusahaan di masukkan kedalam undang-udang ketenagakerjaan, bahwa Pasal 1 angka 14 UU Ketenagakerjaan menyebutkan perjanjian kerja adalah perjanjian antara pekerja/ buruh dengan pengusaha atau pemberi kerja yang memuat syarat-syarat kerja, hak, dan kewajiban para pihak, sedangkan Pasal 1 angka 21 UU Ketenagakerjaan menyebutkan perjanjian kerja bersama adalah perjanjian yang merupakan hasil perundingan antara serikat pekerja/serikat buruh atau beberapa serikat pekerja/serikat buruh yang tercatat pada instansi yang bertanggung jawab di bidang ketenagakerjaan dengan pengusaha, atau beberapa pengusaha atau perkumpulan pengusaha yang memuat syarat-syarat kerja, hak dan kewajiban kedua belah pihak. (

Pengaturan perkawinan dalam dunia kerja, setiap pekerja/buruh dalam satu perusahaan yang akan melangsungkan perkawinan, beberapa 
perusahaan baik pemerintah, maupun swasta, menetapkan suatu klausul yang membatasi hak untuk melangsungkan perkawinan antar pekerja/ buruh dalam satu perusahaan, pembuatan perjanjian kerja ini dibenarkan Undang-undang ketenagakerjaan, terbukti pada Pasal 153 ayat 1 huruffUU ketenagakerjaan dalam frase "kecuali telah diatur dalam perjanjian kerja, peraturan perusahaan atau perjanjian kerja bersama bersama telah mengadopsi prinsip kebebasan berkontrak dalam hukum perjanjian, dimana ketentuan tersebut hanya dapat dilaksanaakan apabila telah disepakati oleh kedua belah pihak melalui suatu perjanjian kerja, peraturan perusahaan dan perjanjian kerja besama. Selain itu, dalam membuat suatu aturan, perusahaan tidak diperkenankan memasukkan ketentuan yang bertentangan dengan ketentuan hukum yang berlaku dimana perusahan tersebut berkedudukan atau berdiri. Ketentuan dalam berkontrak diatur dalam pasal $1320 \mathrm{Kitab}$ Undnag-undang hukum Perdata yang ditentukan "Supaya terjadi persetujuan yang sah, perlu dipenuhi empat syarat

a. kesepakatan merkea yang mengikatnya dirinya;

b. kecakapan untuk membuat suatu perikatan

c. suatu pokok persoalan tertentu

d. suatu sebab yang tidak terlarang

Perjanjian kerja merupakan bagian dari perjanjian yang dimaksud dalam buku III Kitab Undang-undang Hukum Perdata (Selanjutnya disebut KUHPerdata). Sebagai bagian dari buku III KUHperdata maka berlaku asas-asas umum dari suatu perikatan adalah salah satunya asas pacta sun servanda yang diatur dalam pasal 1338 KUHPerdata. Asas pasca sun servanda menyatakn bahwa perjanjian merupakan undangundang bagi yang membuatnya. Undang-undang merupakan bagian dari hukum dan sebagai negara hukum otomatis setiap warga negara harus menaati perjanjian yang dibuatnya karena perjanjian berdasarkan Pasal 1338 KUHPerdata sama dengan Undang-undang bagi yang membuatnya. Perjanjian adalah suatu hubungan hukum anatara dua pihak, dalam mana satu pihak berjanji atau dianggap untuk melakukan sesuatu hal, sedang pihak lain berhak menuntut pelaksanaan janji itu. ${ }^{2}$
Perjanjian kerja bersifat mengikat dikarenakan merupakan hasil kesepakatan para pihak yang harusnya muncul tanpa paksaan sebagaimnaan dimaskud dalam pasal 1320 KUHPerdata yang mengatur syara sahnya perjanjian. Oleh karena itu persetujuan tersebut tidak dapat ditarik kembali selain dengan persetujuan para pihak, yakni pihak pemberi kerja dan pihak penerima kerja.

Persetujuan kedua belah pihak untuk menaati perjanjian kerja, sebelum disepakati perjanjian yang dituangkan dalam klausul perjanjian, para pihak diberikan kebebasan untuk menyepakati isi dari suatu perjanjian atau biasanya disebut dengan asas kebebasan berkontrak. Dalam perjanjian tertuang hak dan kewajiban yang mengikat masing-masing pihak. Asas kebebasan berkontrak dimilik oleh setiap pihak yang mempunyai kepentindan. Kepentingankepentingan antar pihak kemudian dituangkan dalam perjanjian yang didalamnya berisi hak dan kewajiban yang mengikat serta harus disepakati oleh masing-masing pihak yang menyetujuinya. Baik perjanjian kerja bersama dan peraturan perusahaan, pengusaha dapat menerapkan aturan yang mewajibkan kinerja perusahaan serta meningkatkan pelayananan dan sikap profesional dalam bekerja . Pasal 61 ayat 1 huruf d UU ketenagakerjaan mengatur perjanjian kerja berakhir apabila adanya keadaan atau kejadian tertentu yang dicantumkan dalam perjanjian kerja, peraturan perusahaan atau perjanjian kerja bersama yang dapat menyebabkan berakhirnya hubungan kerja, sesuai dengan aturan tersebut perusahaan dapat memutus hubungan kerja.

pasal 153 ayat 1 huruf $f$ UU ketenagakerjaan, aturan ini memberikan celah bagi pengusaha membuat suatu klausul perjanjian kerja, perjanjian kerja sama ataupun peraturan perusahaan yang wajib ditaati sesuai dengan kesepakatan. Apabila pekerja memaksakan untuk melakuk pernikahan degnean sesam pekerja pada satu perusahaan, maka pekerja tersebut telah melakukan wanprestasi dan kepadanya dapat dikenakan sanksi tertentu sesuai dengan ketentuan perushaaan dan ketentuan perundangundangan yang berlaku 
Disamping profesionalisme, larangan adanya ikatan perkawinan dalam satu perusahaan juga dimaksudkan agar tidak adanya terjadinya conflict of interest antara suami dengan istri dalam satu perusahaan. Konflik berkepentingan dapat terjadi ketika individu atau organissi terlibat dalam berbagai kepentingan, sehingga dapat mempengaruhi motivasi untuk bertindak dan berbagai aktivitas lainnya. Hasilnya tentu akan menyulitkan orang bersangkutan dan pihak lainnya dalam menjalankan tugasnya.

Menurut pendapat Thomas Hobbes, suatu perbuatan adil apabila telah didasarkan pada perjanjian perjanjian tertentu. Artinya seseorang yang berbuat berdasarkan perjanjian yang disepakatinya bisa dikatakan adil. Mengenai teori keadilan ini, Notonegoro menambahkan tentang adanya keadailan legalitas atau keadilan hukum, yaitu suatu keadaan dikatakan adil jika sesuai dengan ketentuan hukum yang berlaku. ${ }^{3}$ Sehingga keadilan dipandang sebagai perbuatan yang telah diatur didalam suatu perjanjian. Pekerja yang telah menandatangi suatu perjanjian atau kontrak kerja yang didalamnya termuat suatu perjanjian atau kontrak kerja yang didalamnya termuat suatu aturan bahwa dilarangnya terjadinya suatu ikatan perkawinan harus ditaati ketentuan yang telah disepakati.

Ketentuan norma yang diatur oleh Pasal 153 ayat 1 huruff Undang-undang No 13 tahun 2003 bertujuan untuk melindungi kepentingan yang lebih besar untuk menjaga hak setiap orang yang bekerja guna mendapatkan perlakukan adil, dalam hal ini juga diatur dalam konstitusional Pada Pasal 28J Ayat 1 UUD NRI 1945 bahwa setiap orang wajib menghormati hak asasi manusia orang alin dalam tertib kehidupan bermasyarakat, berbangsa dan bernegara dan ayat 2 ditentukan "dalam menjalankan hak dan kebebasannya setiap orang wajib tunduk kepada pembatasan yang ditetapkan undang-undang dengan maksud semata-mata untuk menjamin pengakuan serta penghormatan atas hak dan kebebasan orang lain dan untuk memenuhi tuntutan yang adil sesuai dengan pertimbangan moral, nilai-nilai agama dan ketertiban umum dalam suatu masyarakat demokratis.

Moral atau budi nurani merupakan suatu kaidah yang timbul dari dalam diri manusia dalam bentuk nilai-nilai kemanusiaan yang menjadi ukuran baik dan buruk tentang sikap dan perilaku manusia. Kemudian, moral atau budi nurani ini dapat bersifat obyektif dalam suatu komunitas atau masyarakat yang menimbulkan kaidah moral positif

Selanjutnya, mengenai etika, yang didefinisikan oleh R. Wayne Mondy sebagai suatu disiplin yang berkaitan dengan apa yang baik dan buruk, yang benar atau yang salah, atau dengan kewajiban dan tanggung jawab moral. ${ }^{4}$ Untuk mewujudkan ketertiban yang berkeadilan tentunya dibutuhkan upaya, salah satunya adalah melalui peraturan perundang-undangan. Demi menjamin hak asasi manusia dan kebebasan dasarnya, ketertiban umum, dan kepentingan bangsa, maka beberapa hak memang sebaiknya dibatasi apabila implementasi hak tersebut dapat menciderai hak asasi manusia dan kebebasan dasar orang lain, menimbulkan ketidaktertiban, dan mengorbankan kepentingan bangsa. Salah satunya adalah hak untuk berkeluarga. Undang-Undang Perkawinan mengatur syarat-syarat perkawinan yang merupakan pembatasan hak untuk berkeluarga, salah satunya adalah pembatasan usia. Kemudian ada larangan- larangan menikah yang mencegah terjadinya perkawinan yang bertentangan dengan kesusilaan, hukum agama, dan peraturan-peraturan lainnya.

Merujuk pada daftar kepentingan yang dibuat oleh Pound, maka yang harus diutamakan adalah kepentingan umum. Oleh karena itu pembatasan suatu hak asasi manusia harus melihat pada kepentingan tersebut. Suami-istri yang bekerja di dalam satu perusahaan memiliki dampak negatif, salah satunya adalah dapat terciptanya budaya kolusi, korupsi, nepotisme. Suatu badan hukum, khususnya badan hukum atau perusahaan publik harus menghindari hal-hal tersebut. Salah satu upaya untuk mencapai tujuan tersebut adalah dengan membuat aturan yang membatasi sesama pekerja untuk menikah, batasan di sini maksudnya adalah salah satu harus 
mengundurkan diri atau di-PHK, di mana hal ini diizinkan oleh pasal 153 huruf fUndang-Undang Ketenagakerjaan selama hal tersebut sudah diatur di dalam Perjanjian Kerja atau Peraturan Perusahaan atau Perjanjian Kerja Bersama.

\section{Kedudukan Hak Tenaga Kerja yang Melangsungkan Perkawinan dengan sesama tenaga kerja dalam satu perusahaan Pasca Putusan Mahkamh Konstitusi Nomor 13/ PUU-XV/2017}

Suatu sistem, unsur-unsur atau bagianbagiannya saling berinteraksi. Ketika unsur-unsur atau bagian-bagian tersebut berinteraksi, maka dimungkinkan terjadinya akan adanya konflik. Menurut Sudikno Mertokusumo, sistem merupakan tatanan atau kesatuan yang utuh yang terdiri dari bagian-bagian atau unsur-unsur yang saling berkaitan erat satu sama lain, atau dengan kata lain sistem hukum adalah suatu kumpulan unsur-unsur yang ada dalam interaksi satu sama lain yang merupakan satu kesatuan yang terorganisasi dan kerja sama ke arah tujuan kesatuan. Hukum adalah suatu sistem. Sistem hukum di sini terdiri dari peraturan, putusan, pengadilan, lembaga atau organisasi dan nilai-nilai, di mana keseluruhan unsur- unsur tersebut merupakan suatu hal yang kompleks. ${ }^{5}$

Sehubungan dengan permasalahan yang muncul terkait pembatasan hak untuk melangsungkan perkawinan antara sesama pekerja dalam satu perusahaan, maka jawabannya pun harus dicari dalam sistem hukum Indonesia. Ditinjau dari Undang-Undang No 39 Tahun 1999 tentang Hak Asasi manusia (selanjutnya disebut UU HAM) dan Undang-Undang Ketenagakerjaan, maka penulis menyimpulkan bahwa ada inkonsistensi antara undang-undang yang satu dengan yang lainnya terkait hak untuk berkeluarga antara sesama pekerja dalam satu perusahaan. Pasal 153 ayat 1 huruf f, UU Ketenagakerjaan yang mengatur klausula alasanalasan yang dilarang oleh undang-undang perihal Pemutusan Hubungan Kerja (PHK) oleh pengusaha. apabila menggunakan penafsiran secara argumentum a contrario, maka dapat disimpulkan bahwa pembatasan hak untuk melangsungkan perkawinan tersebut diperkenankan oleh UU Ketenagakerjaan. Pasalpasal dalam UU HAM yang relevan untuk dikaitkan dengan Pasal 153 ayat 1 huruff tersebut adalah Pasal 10 UU HAM yang menentukan: "Setiap orang berhak membentuk keluarga dan melanjutkan keturunan melalui perkawinan yang sah." dan pasal 38, ayat 1, yakni: "Setiap warga negara, sesuai dengan bakat, kecakapan, dan kemampuan berhak atas pekerjaan yang layak.", serta ayat 2, yang mengatur bahwa setiap orang berhak dengan bebas memilih pekerjaan yang disukainya dan berhak pula atas syarat-syarat ketenagakerjaan yang adil. Lebih lanjut pasal yang dilanggar oleh pasal 153 ayat 1 huruf f UU Ketenagakerjaan, Pasal 6, ICESCR yang berbunyi: "Negara Pihak dari Kovenan ini mengakui hak atas pekerjaan, termasuk hak setiap orang atas kesempatan untuk mencari nafkah melalui pekerjaan yang dipilih atau diterimanya secara bebas, dan akan mengambil langkahlangkah yang tepat guna melindungi hak ini." Mengingat pasal-pasal yang telah dipaparkan sebelumnya, maka dapat disimpulkan pasal 153 ayat 1 huruf fUU Ketenagakerjaan sebenarnya membatasi Hak Asasi Manusia untuk berkeluarga dan untuk memperoleh pekerjaan yang layak sesuai dengan bakat, kecakapan, dan kemampuan.

Kepastian memiliki arti "ketentuan; ketetapan" sedangkan jika kata kepastian itu digabungkan dengan kata hukum menjadi Kepastian Hukum, yang memiliki arti "perangkat hukum suatu negara yang mampu menjamin hak dan kewajiban setiap warga negara". ${ }^{6}$ Secara konstitusional, salah satu hak yang dapat dibentuk ialah hak untuk berkeluarga, dalam hal ini pelaksanaan hak untuk berkeluarga diatur olehjuga didalam undang-undang. Hak berkeluarga merupakan salah satu hak asasi manusia yang telah diakui oleh konstitusional di dalam ketentuan Pasal 28B ayat 1 UUD NRI 1945, menyatakan bahwa "setiap orang berhak membentuk keluarga dan melanjutkan keturunan melalui perkawinan yang sah.” Kepastian hak untuk berkeluarga telah diatur dan konstitusional menjamin serta melindungi setiap 
warga negara. Berpijak dari teori kepastian hukum yakni "sicherkeit des Rechts selbst" (kepastian tentang hukum itu sendiri). Ada empat hal yang berhubungan dengan makna kepastian hukum. Pertama, bahwa hukum itu positif, artinya bahwa ia adalah perundang-undangan (gesetzliches Recht). Kedua, bahwa hukum itu didasarkan pada fakta (Tatsachen), bukan suatu rumusan tentang penilaian yang nanti akan dilakukan oleh hakim, seperti "kemauan baik", "kesopanan". Ketiga, bahwa fakta itu harus dirumuskan dengan cara yang jelas sehingga menghindari kekeliruan dalam pemaknaan, di samping itu juga mudah dijalankan. Keempat, hukum positif itu tidak boleh sering diubah-ubah. ${ }^{7}$

Apabila dikaji dari perspektif hirakhir peraturan perundang-undangan, suatu undangundang harus ditinjau berdasarkan norma hukum yang paling tinggi yaitu Undang-Undang Dasar 1945 yang mengatur mengenai Hak Asasi Manusia. Pembatasan hak untuk berkeluarga tersebut harus dihubungkan dengan pasal 28B, ayat 1 , yang menyatakan "Setiap orang berhak membentuk keluarga dan melanjutkan keturunan melalui perkawinan yang sah.”Kemudian mengenai hak atas pekerjaan diatur dalam pasal 27, ayat 2, yang mengatur bahwa tiap-tiap warga negara berhak atas pekerjaan dan penghidupan yang layak. Hak ini diatur lebih lanjut dalam pasal 28D, ayat 2 , yang menyatakan "Setiap orang berhak untuk bekerja serta mendapat imbalan dan perlakuan yang adil dan layak dalam hubungan kerja." Adapun pembatasan terhadap Hak Asasi Manusia ada dalam pasal 28J, ayat 2, sematamata untuk menjamin pengakuan serta penghormatan atas hak dan kebebasan orang lain dan untuk memenuhi tuntutan yang adil sesuai dengan pertimbangan moral, nilai-nilai agama, keamanan, dan ketertiban umum dalam suatu masyarakat demokratis. Lebih lanjut, mengenai pembatasan ini pun diatur dalam pasal 73 UU HAM yang menentukan: "Hak dan kebebasan yang diatur dalam undang-undang ini hanya dapat dibatasi oleh dan berdasarkan undang-undang semata-mata untuk menjamin pengakuan dan penghormatan terhadap hak asasi manusia serta kebebasan dasar orang lain, kesusilaan, ketertiban umum, dan kepentingan bangsa."

Tradisi hukum di Indonesia berasal dari Eropa Kontinental (civil law system), tetapi tidak mengesampingkan keberadaan yurisprudensi. Putusan Makamah Kontitusi tidak lain merupakan suatu yurisprudensi. Ada beberapa alasan yang mendukung mengapa sebuah Putusan Makamah Konstitusi kemudian dapat dikategorikan sebagai suatu yurisprudensi. Pertama, Purnadi Purbacaraka dalam Soeroso mengemukakan isitilah yurisprudensi berasal dari kata yurisprudentia yang berarti pengetahuan hukum. Adapun dalam bahasa jerman, kata yurisprudensi diartikan ilmu hukum. ${ }^{8}$ Jadi Putusan Makamah Konstitusi sesungguhnya kaya akan akan muatan ilmu hukum, sebagai contoh dalam pertimbangan hukum Makamah Konstitusi yang terdapat dalam Putusan No. 13/PUU-XV/2017, dimuat pembahasan tentang prinsip negara hukum dan korelasi antara peristiwa hukum dengan akibat hukum. Kedua, yurisprudensi merupakan putusan pengadilan yang telah memiliki hukum tetap dan menurut pendapat Muhtadin Dg. Mustafa, putusan ini dapat pula digunakan oleh hakim yang lain sebagai referensi hukum. ${ }^{9}$ Hal ini bersesuian dengan Putusan Makamah Kontitusi yang bersifat final and binding berdasarkan penjelasan Pasal 10 dalam Undang-undang No. 8 Tahun 2011 tentang Perubahan Atas Undang-undang No. 24 Tahun 2003 tentang Makamah Kontitusi.

Jika dikaitkan kemudian dengan tujuan politik hukum nasional menurut Philippe Nonet dan Philip Selznick, Putusan Makamah Konstitusi sebagai yuriprudensi ternyata memiliki fungsi penting di dalam menciptakan sebuah sistem hukum nasional yang rasional, transparan, demokratis, otonom dan responsif terhadap perkembangan, aspirasi, ekspektasi masyarakat. ${ }^{10}$ Dalam bahasa yang lebih disederhanakan, Putusan Makamah Konstitusi sebagai yurisprudensi merupakan instrument kontrol terhadap segenap produk hukum yang dianggap tidak sesuai lagi dengan kebutuhan masyarakat atau cenderung tertinggal dari suatu peristiwa, bahkan produk hukum yang bersifat inkonstitusional. 
Misalnya terhadap keberadaan Pasal 153 ayat 1 huruf $\mathrm{f}$ UU ketenagakerjaan yang pada mulanya memberikan klausul yang membatasi hak untuk melangsungkan perkawinan antar pekerja/ buruh dalam satu perusahaan, pembuatan perjanjian kerja ini dibenarkan Undang-undang ketenagakerjaan, terbukti pada Pasal 153 ayat 1 huruf fUU ketenagakerjaan dalam frase "kecuali telah diatur dalam perjanjian kerja, peraturan perusahaan atau perjanjian kerja bersama bersama. Ketentuann tersebut pada intinya mengadopsi prinsip kebebasan berkontrak dalam hukum perjanjian, dimana ketentuan tersebut hanya dapat dilaksanaakan apabila telah disepakati oleh kedua belah pihak melalui suatu perjanjian kerja, peraturan perusahaan dan perjanjian kerja besama. Namun ketentuan pasal ini dianggap inkonstitutsional dan tidak sesuai lagi dengan hak yang telah diatur oleh Pasal 28D ayat 2 UUD NRI 1945

Berdasarkan ketentuan Pasal 28I ayat 4 UUD NRI 1945 menegaskan "perlindungan, pemajuan, penegakan, dan pemenuhan hak assi mansusia adlaah tanggung jawab negara, terutam pemerintah" oleh karena itu, terlepas dari jenis atau kategorinya, tanggungjawab negara sebagaimana dimaksud daam Pasal 28I aayt 4 UUD NRI 1945 tetap melekat pada negaram, khususnya Pemerintah. Hal itu a qua, dalam hak ini khususnya hak untuk bekerja serta mendapatkan imbalan dan perlakuan yang layak dan adil dalam hubungan kerja serta hak untuk membentuk keluarga dan melanjutkan keturuan melalui perkawinan yang sah. Meskipun tanggung jawaba untuk melinfungi, memajukan dan memenuhi hak asasi masnusia itu oleh Konstitusi ditegaskan menjadi tanggung jawba negara, khususnya negara tidak wajib menghormati keberadaan hak-hak tersebut. Sebab esensi setiap hak yang dimiliki seseorang selalu menimbulan kerwajiban pada pihak atau orang lainnya menghormatinya keberadaan hak itu. Bahwa apabila ketentuan yang terdapat UUD 1945, UU HAM, Deklarasi Universal Hak Asasi Manusia, dan International Covenant on Economic, Social, and Cultural Rights tersebut dikaitkan dengan Pasal 153 ayat (1) huruf fUU
Ketentagakerjaan yang secara $a$ contrario berarti bahwa dalam suatu perusahaan yang mempersyaratkan pekerja/buruh tidak boleh mempunyai pertalian darah dan/atau ikatan perkawinan dengan pekerja/buruh lainnya di dalam satu perusahaan dan menjadikan hal itu sebagai dasar dapat dilakukannya pemutusan hubungan kerja terhadap pekerja/buruh yang bersangkutan, Mahkamah menilai bahwa aturan tersebut tidak sejalan dengan norma dalam Pasal 28D ayat (2) UUD 1945 maupun Pasal 38 ayat (1) dan ayat (2) UU 39/1999, Pasal 6 ayat (1) International Covenant on Economic, Social, and Cultural Rights (Kovenan Internasional tentang Hak-Hak Ekonomi, Sosial, dan Budaya) yang telah diratifikasi oleh Undang-Undang Nomor 11 Tahun 2005, dan Pasal 23 ayat (1) Deklarasi HAM PBB sebagaimana disebutkan di atas. Pertalian darah atau hubungan perkawinan adalah takdir yang tidak dapat direncanakan maupun dielakkan. Oleh karena itu, menjadikan sesuatu yang bersifat takdir sebagai syarat untuk mengesampingkan pemenuhan hak asasi manusia, dalam hal ini hak atas pekerjaan serta hak untuk membentuk keluarga, adalah tidak dapat diterima sebagai alasan yang sah secara konstitusional. Sesuai dengan Pasal 28J ayat (2) UUD 1945 pembatasan terhadap hak asasi manusia hanya dapat dilakukan dengan maksud semata-mata untuk menjamin pengakuan serta penghormatan atas hak dan kebebasan orang lain dan untuk memenuhi tuntutan yang adil sesuai dengan pertimbangan moral, nilainilai agama, keamanan, dan ketertiban umum dalam suatu masyarakat demokratis.

Mahkamah konstitusi memberikan argumentasi, tidak selalu relevan untuk diterapkan tanpa memperhatikan keseimbangan kedudukan para pihak yang membuat persetujuan tersebut ketika persetujuan itu dibuat. Dalam kaitan ini, telah terang kiranya bahwa antara Pengusaha dan pekerja/buruh berada dalam posisi yang tidak seimbang. Sebab pekerja/buruh adalah pihak yang berada dalam posisi yang lebih lemah karena sebagai pihak yang membutuhkan pekerjaan. Dengan adanya posisi yang tidak seimbang tersebut, maka dalam hal ini filosofi kebebasan 
berkontrak yang merupakan salah satu syarat sahnya perjanjian menjadi tidak sepenuhnya terpenuhi. Berdasarkan pertimbangan demikian maka kata "telah" yang terdapat dalam rumusan Pasal 153 ayat (1) huruf UU Ketenagakerjaan tidak dengan sendirinya berarti telah terpenuhinya filosofi prinsip kebebasan berkontrak.

Pasca dikeluarkan Putusan Mahkamah Konstitusi No 13/PUU-XV/2017 sebagai sebuah yurisprudensi, maka tenaga kerja yang melakukan perkawinan antar sesama tenaga kerja dalam satu perusahaan tidak dapat dipecat dari perusahaan tersebut. Dengan demikian, hak dan kewajiban tenaga kerja yang dimaksud tetap berjalan sebagaimana mestinya.

\section{B. PENUTUP}

\section{a. Simpulan}

1. Sebelum Putusan Mahkamah Konstitusi No. 13/PUU-XV/2017 pada prinsipnya dapat melangsungkan perkawinan sesama tenaga kerja dalam satu perusahaan namun disisi lain menimbulkan polemik dengan adanya klausul yang menyatakan bahwa Pasal 153 ayat 1 huruf fUndang-undang No 13 tahun 2003 terdapat frasa: "kecuali telah diatur dalam perjanjian kerja, peraturan perusahaan atau perjanjian kerja bersama bersama. Suatu klausul yang dapat membatasi hak untuk melangsungkan perkawinan antar pekerja/buruh dalam satu perusahaan yang dituangkan berupa perjanjian ataupun bentuk peraturan perusahaan.

2. kedudukan hukum tenaga kerja yang memiliki ikatan perkawinan dengan sesama tenaga kerja dalam satu perusahaan pasca Putusan MK Nomor 13/PUU-XV/2017 tidak dapat dipecat dari perusahaan tersebut. Dengan demikian, hak dan kewajiban tenaga kerja yang dimaksud tetap berjalan sebagaimana mestinya.

\section{b.Saran}

1. Kepada setiap pengusaha hendaknya memberikan kesempatan bagi tenaga kerja untuk melangsungkan perkawinan sesuai dengan keinginan tenaga kerja tersebut.
2. Kepada setiap perusahaan diharapkan merevisi peraturan perusahaan, perjanjian kerja dalam hal kedudukan hukum tenaga kerja yang memiliki ikatan perkawinan dalam satu perusahaan dengan menyesuaikan pada Putusana Mahkamah Konstitusi Nomor 13/ PUU-XV/2017

\section{DAFTAR PUSTAKA}

\section{BUKU.}

Abdul Manna, 2008, aneka masalah Hukum perdata Islam di Indonesia, Kencana Prenada Media Group, Jakarta

Aim Abdulkarim, 2006, Pendidikan Kewarganegaraan, Grafindo Media Pratama, Jakarta,

B. Arief Sidharta, Ilmu Hukum Indonesia Upaya Pengembangan Ilmu Hukum Sistematik yang Responsif terhadap Perubahan Masyarakat, Unpar Press, Bandung, 2016 E. Fernando M. Manullang, 2007, Menggapai Hukum Berkeadilan Tinjauan Hukum Kodrat dan Antinomi Nilai, Kompas, Jakarta

Imam Syakuni, A. Ahsin Thohari, 2013, Dasardasar Politik Hukum, cet. 9, PT RajaGrafindo Persada, Jakarta,

R. Soeroso, 2011, Pengantar Ilmu Hukum, Cet. 11, Sinar Grafika, Jakarta

R. Wayne Mondy, 2008, Manajemen Sumber Daya Manusia, Erlangga, Jakarta

Satjipto Rahardjo, 2006, Hukum dalam Jagad Ketertiban, UKI Press, Jakarta

Sudikno Mertokusumo, 2000 Penemuan Hukum, Liberty, Yogyakarta

Wirjono Prodjodikoro, 1985, Hukum Perdata tentang Persetujuan-Persetujuan Tertentu, Bandung: Sumur

\section{JURNAL}

Muhtadin Dg. Mustafa, 2004, Pemberdayaan Yurisprudensi Sebagai Sumber Hukum Islam (Analisis Fungsional Dalam Rangka Optimalisasi Kinerja Hakim Di Indonesia), Jurnal Hunafa, vol. 1. No. 1, Palu, 
PERATURAN

UNDANGAN

Undang-undang Dasar Negara Republik Indonesia 1945

Undang - undang Nomor 1 Tahun 1974 tentang Perkawinan

Undang- undang Nomor 13 Tahun 2003 tentang Ketenagakerjaan

Undang - undang Nomor 39 tahun 1999 tentang Hak Asasi Manusia

Putusan Mahkamah Konstitusi No 13/PUU-XV/ 2017

\section{(Footnotes)}

${ }^{1}$ Abdul Manna, 2008, Aneka Masalah Hukum perdata Islam di Indonesia, Kencana Prenada Media Group, Jakarta, hlm 1

${ }^{2}$ Wirjono Prodjodikoro, 1985, Hukum Perdata tentang Persetujuan-Persetujuan Tertentu,Sumur, Bandung.

3 Aim Abdulkarim, 2006, Pendidikan Kewarganegaraan
, Grafindo Media Pratama, Jakarta, hlm. 58

${ }^{4}$ R. Wayne Mondy, 2008, Manajemen Sumber Daya Manusia, Erlangga, Jakarta, hlm., 30(

5 Sudikno Mertokusumo, 2000, Penemuan Hukum, Liberty, Yogyakarta, hlm., 18-20

${ }^{6}$ E. Fernando M. Manullang, 2007, Menggapai Hukum Berkeadilan Tinjauan Hukum Kodrat dan Antinomi Nilai, Kompas, Jakarta, hlm. 91-92.

${ }^{7}$ Satjipto Rahardjo, 2006, Hukum dalam Jagad Ketertiban, UKI Press, Jakarta, hlm. 135136.

${ }^{8}$ R. Soeroso, 2011, Pengantar Ilmu Hukum, Cet. 11, Sinar Grafika, Jakarta, hlm. 159

${ }^{9}$ Muhtadin Dg. Mustafa, 2004, Pemberdayaan Yurisprudensi Sebagai SumberHukum Islam (Analisis Fungsional Dalam Rangka Optimalisasi Kinerja Hakim Di Indonesia), Jurnal Hunafa, vol. 1. No. 1, Palu, hlm. 49-50

${ }^{10}$ Imam Syakuni, A. Ahsin Thohari, 2013, Dasardasar Politik Hukum, cet. 9, PT RajaGrafindo Persada, Jakarta, hlm. 72 